\title{
АНАЛИТИЧЕСКОЕ СОПРОВОЖДЕНИЕ ТЕХНОЛОГИИ ДЕМЕРКУРИЗАЦИИ ТВЕРДЫХ ОТХОДОВ
}

\author{
Левченко Л.М. ${ }^{1}$, Минин В.А. ${ }^{3}$, Сагидуллин А.К. ${ }^{1}$, Сапрыкин А.И. ${ }^{1,2}$, Троицкий Д.Ю. ${ }^{1}$ \\ ${ }^{1}$ ФГБУН Институт неорганической химии им. А.В. Николаева СО РАН, Новосибирск, \\ Россия \\ ${ }^{2}$ Новосибирский национальный исследовательский государственный университет, \\ Новосибирск, Россия \\ ${ }^{3}$ ФГБУН Институт геологии и минералогии им. В.С. Соболева СО РАН, \\ Новосибирск, Россия \\ luda@niic.nsc.ru
}

DOI: 10.26902/ASFE-11_40

Разработка технологий демеркуризации твердых отходов является чрезвычайно актуальной проблемой, поскольку ртуть - хорошо известный суперэкотоксикант и, согласно действующим в нашей стране экологическим и гигиеническим нормативам, предельно допустимые концентрации (ПДК) ртути в воздухе составляют 0,0003 мг/м ${ }^{3}$, в почве $-2,1$ мг/кг.

Для разработки технологии демеркуризации строительных отходов и грунтов ОАО НЗХК были использованы методы гравитационной сепарации в водной среде для извлечения металлической ртути из строительных отходов и химической иммобилизации ртути для перевода отходов из 1 класса опасных в 4 класс безопасные.

Разработка технологии демеркуризации невозможна без аналитического сопровождения каждой стадии процесса.

В начале в исходных отходах было определено содержание ртути методом ААС (содержание ртути определяли в растворах на ртутном анализаторе «Юлия-2») от 0,045 $\pm 0,015$ мас. \% до 7,4 $\pm 1,1$ мас. \%, превышающей норму ПДК в 150-30000 раз, согласно ПНДФ 14.1.2.20-95.

После гравитационной сепарации и обезвоживания содержание ртути в хвостах обогащения строительных отходов снизилось до $0.009 \%$, грунтов $0.141 \%$. Степень извлечения металлической ртути в итоге для строительных отходов составила $80 \%$, для грунтов - $98 \%$.

Процесс химической иммобилизации ртути, адсорбированной на поверхности строительных отходов, проводили введением расчетного количества окислителей с последующим взаимодействием с раствором полисульфидом кальция, в результате чего образовывался нерастворимый и малолетучий сульфид ртути. Расчет количества раствора полисульфила кальция проводили по сере. Для определения сульфидной серы в растворе полисульфида кальция нами была разработана оригинальная спектрофотометрическая методика.

Демеркуризированные отходы анализировали на класс опасности и степень их утилизации. Отбор проб, анализ и определение класса опасности токсичных отходов производили в соответствии с действующими правилами согласно ГОСТ Р 51768, ПНД. Ф 14.1:2. 20, М 03-06-2000. В полученных отходах содержание ртути регистрировали на уровне менее 2,1 мг/кг (ПДК для почвы), а в фильтратах после осветления содержание ртути не превышало 0,0005 мг/л (ПДК для воды). Содержание ртути определяли методом ААС с золотым сорбентом.

Определение содержания ртути в воздухе на выходе из адсорбера проводили согласно ПНД Ф 14.1:2.20.

Иммобилизация остаточной ртути в грунтах и строительных отходах позволила снизить их класс опасности (по данным биотестирования) до четвертого безопасного.

Разработанная технология и созданная на ее основе опытно-промышленная установка обеспечивает переработку ртутьсодержащих твердых отходов с производительностью до 0,2 т/ч. 